\title{
Методика розробки математичної моделі електромобіля відповідно до його компонувальної схеми
}

\begin{abstract}
Екологічні, економічні та транспортні проблеми міст спонукають людство до пошуку нових транспортних засобів та способів організації міських перевезень. На сьогоднішній день використання електромобілів у розвинених краӥнах поступово збільшується. Виробництво та реалізація електромобіля є актуальним, оскільки на таку продукцію існує потенційний попит з боку споживачів. Також питання утилізації існуючих автомобілів, обладнаних ДВЗ, враховуючи їх велику кількість, створює значну суспільну проблему. Одним зі способів ії вирішення $\epsilon$ їх переобладнання в гібридні та електромобілі. Дуже часто таке переобладнання здійснюється власниками старих автомобілів з ДВЗ, при ияьому не проводиться жодних досліджень з його доцільності. Відсутність методики обчислення експлуатаційних властивостей переобладнаних транспортних засобів ускладнює цей прочес.

Розробка методики для складання математичної моделі силової установки та руху переобладнаного транспортного засобу категорій M1 ma N1 є актуальним завданням. За допомогою якого було б можливим визначення його експлуатаційних показників. Для розробки методики складання математичної моделі руху електромобіля обрана компонувальна схема передньопривідного автомобіля. Стосовно механічної системи електромобіля з одним ступенем вільності для математичного опису динамічних процесів використано рівняння руху в узагальнених координатах - рівняння Лагранжу. Для визначення узагальненої сили обчислена елементарна робота всіх сил та моментів, щчо діють на автомобіль під час його руху. Як узагальнену координату в електроприводі прийнято кутове переміщення вала електродвигуна, до якого приведені параметри всіх механічних ланок системи. Отримано рівняння руху електромобіля, що відповідає його компонувальній схемі.
\end{abstract}

Ключові слова: електромобіль; переобладнання; ефективність; математична модель; силовий баланс; сила; момент; рівняння руху; експлуатаційні показники.

Актуальність теми. На сьогоднішній день використання електромобілів у розвинених країнах поступово збільшується. За даними статистичних досліджень ринок електромобілів показує високі темпи росту [1]. Світовий парк екологічно чистих автомобілів зараз нараховує близько 800 тис. одиниць, український при цьому - всього лише 1000 електромобілів. Виробництво та реалізація електромобіля $\epsilon$ актуальним, оскільки на таку продукцію існує потенційний попит з боку споживачів. Це зумовлено такими факторами, як його економічність, екологічність та зручність у використанні. Проте на даний момент існують проблеми 3 наявністю розгалуженої мережі станцій електричного живлення та складності технічного обслуговування.

Вирішити проблему малого запасу ходу електромобіля можливо застосувавши гібридні автомобілі 3 додатковим двигуном внутрішнього згоряння. Проте такий спосіб має свої переваги та недоліки [2]. Лідером у світі за показником розповсюдження електромобілів серед усіх типів авто є Норвегія - частка «зелених» машин становить близько 24 \% від загального обсягу продажів автомобілів у цій країні. На другому місці - Швеція з часткою ринку близько 3 \% для машин з електротягою. За ними йдуть Ісландія, Нідерланди, Швейцарія, Франція, Бельгія, Австрія та Великобританії - на продаж електромобілів в цих країнах припадає понад 1 \% від загального обсягу автомобільного ринку [3].

Аналіз останніх досліджень та публікації, на які спирається автор. Сьогодні спостерігається стійка тенденція до переобладнання автомобілів з ДВЗ в автомобілі з гібридною силовою установкою та електромобілі. Дуже часто таке переобладнання здійснюється власниками старих автомобілів з ДВ3, при цьому не проводиться жодних досліджень з його доцільності. Відбувається встановлення тягового електродвигуна за принципом: «що маємо». Так само обираються інші функціональні елементи електромобіля. При такому переобладнанні досягти поліпшення будь-яких експлуатаційних показників електромобіля не можливо. Відсутність методики обчислення експлуатаційних властивостей переобладнаних транспортних засобів ускладнює цей процес.

Сьогодні головним нормативним технічним документом, згідно з яким проводяться сертифікаційні дослідження експлуатаційних показників електромобілів, гібридних автомобілів категорій M1 та N1, $\epsilon$

(C) О.М. Тімков, В.С. Гладченко, М.М. Гордієнко, 2019 
правила ЄЕК ООН № 101-02:2005 [4]. Головним оціночним показником ефективності електромобіля вважається витрата електроенергії, яка на сьогодні не нормується. Вона визначаються за формулою:

$$
c=\frac{E}{D_{\text {test }}},
$$

де $E$ - результати вимірювань зарядки електричної енергії під час випробувань, Вт*год;

$D_{\text {test }}$ - відстань, пройдена під час випробувань, км.

Проведений аналіз витрати електроенергії серійних електромобілів та гібридних автомобілів 3 електричною силовою установкою в [5] показує, що більшість транспортних засобів мають витрату електроенергії в діапазоні 80...140 Вт*год/км (рис. 1). При цьому цей показник розраховувався за даними, що надають автовиробники. Насправді ці значення можуть мати значну відмінність, що обумовлено великою кількістю факторів.

Як зазначалося раніше, сьогодні величина показника витрати енергії не нормується. Опосередковано iii значення можна порівняти 3 діючим раніше ГОСТом 8802-78 [6] для трамваїв, в якому питоме енергоспоживання на тягу при умовній розрахунковій швидкості 25 км/год не мало перевищувати 100 Вт*год на т*км. Отже, оскільки в середньому електромобілі важать близько однієї тонни, 3 цього можна зробити висновок, що значення витрати енергії близько 100 Вт*год/км - $\epsilon$ нормальною. Однак чим меншим $є$ цей показник, тим більш ефективним є робота всіх функціональних елементів електромобіля та його системи керування, тим краще для споживача.

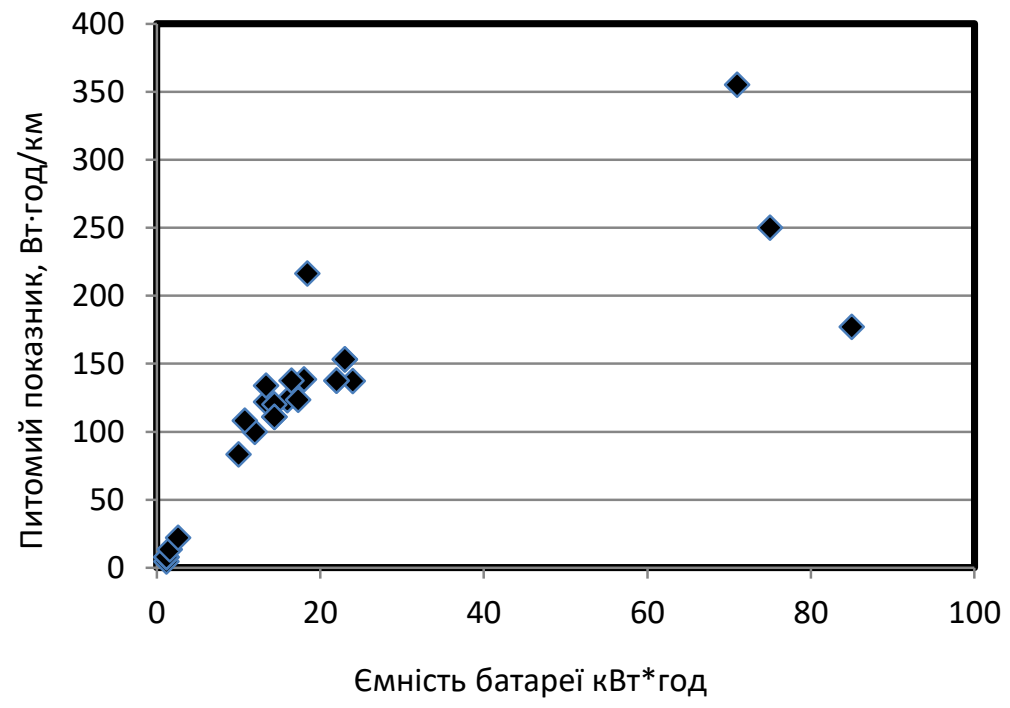

Рис. 1. Розподіл витрати енергї̈ серійними електромобілями та гібридами

Метою статті є розробка методики для складання математичної моделі силової установки та руху переобладнаного транспортного засобу категорій M1 та N1. За допомогою якої було б можливим визначення його експлуатаційних показників.

Викладення основного матеріалу. Тяговий електропривод (ТЕП) електромобіля (рис. 2) в загальному випадку структурно містить джерело електричної енергії (ДЕЕ), електродвигун (ЕД) і механічну трансмісію (МТ), яка передає механічне зусилля від ЕД до ведучих коліс (ВК) електромобіля.

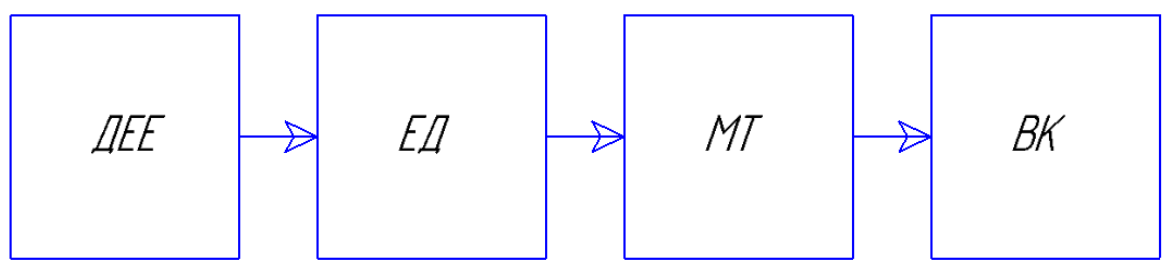

Рис. 2. Схема тягового електроприводу електромобіля

Для розробки методики складання математичної моделі руху електромобіля обрана компонувальна схема передньопривідного автомобіля, наведена на рисунку 3 , яка відрізняється простотою механічної 
трансмісії, підвищеним ККД, високими масогабаритними показниками електроприводу, а також підвищеною надійністю. Для математичного опису динамічних процесів, що відбуваються в механічній частині електроприводу, використовують рівняння руху в узагальнених координатах - рівняння Лагранжу $[7,8]$ :

$$
\frac{d}{d t}\left(\frac{\partial E_{k}}{\partial \dot{q}_{i}}\right)-\frac{\partial E_{k}}{\partial q_{i}}=Q_{i},
$$

де $E_{k}$ - накопичена кінетична енергія системи, визначена через узагальнені координати $q_{i}$ та узагальнені швидкості $\dot{q}_{i}$;

$Q_{i}=\partial A_{i} / \partial q_{i}-$ узагальнена сила обумовлена сумою елементарних робіт $\partial A_{i}$ всіх діючих сил на можливому переміщенні $\partial q_{i}$.

Як узагальнену координату $q_{i}$ в електроприводі, як правило, приймають кутове переміщення $\varphi$ вала ЕД, до якого приводяться параметри всіх механічних ланок системи $[7,8]$. Розглядаючи механічну систему електромобіля з одним ступенем вільності та узагальненою координатою - кутом $\varphi$ повороту вала ТЕП, рівняння (2) запишемо у вигляді:

$$
\frac{d}{d t}\left(\frac{\partial E_{k}}{\partial \dot{\varphi}_{i}}\right)-\frac{\partial E_{k}}{\partial \varphi_{i}}=Q_{i},
$$

де $E_{k}$ - накопичена кінетична енергія електромобіля;

$\dot{\varphi}-$ кутова швидкість вала тягового електродвигуна;

$Q-$ узагальнена сила, що діє на переміщенні $\varphi$.

На підставі обраної схеми ТЕП складена узагальнена розрахункова механічна схема електромобіля [7], а наведена на рисунку 3.

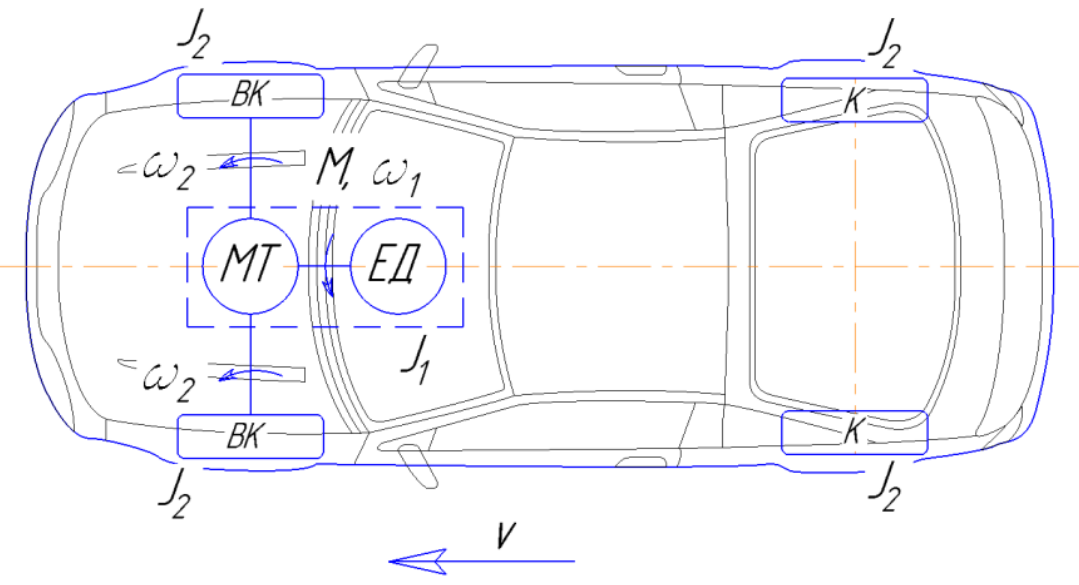

Рис. 3. Розрахункова механічна схема електромобіля

Отримаємо рівняння руху, відповідно до розрахункової схеми на рисунку 3. Запас кінетичної енергії електромобіля $E_{k}$ визначається сумою кінетичних енергій ТЕП з редуктором $E_{1}$, кузова електромобіля і вантажем $E_{0}$ та чотирьох коліс автомобіля $4 E_{2}$ :

$$
E_{k}=E_{0}+E_{1}+E_{2} .
$$

Розкриємо значення кінетичної енергії для кожного з елементів рівняння (4), одержимо:

$$
E_{k}=\frac{1}{2}\left(\left(m_{0}+m_{1}+4 m_{2}\right) v^{2}+J_{1} \omega_{1}^{2}+4 J_{2} \omega_{2}^{2}\right),
$$

де $m_{0}, m_{1}, m_{2}$ - відповідно, маса кузова електромобіля з вантажем, маса ТЕП , маса колеса;

$v$ - лінійна швидкість електромобіля;

$\omega_{1}, \omega_{2}$ - кутова швидкість вала ТЕП з редуктором та колеса, відповідно;

$J_{1}, J_{2}-$ моменти інерції ТЕП з редуктором та колеса, відповідно.

Враховуючи, що передаточне відношення редуктора визначається як $U=\omega_{1} / \omega_{2}$ та лінійна швидкість колеса електромобіля $v=\omega_{2} R$, вираз (5) перетворимо до виду: 


$$
E_{k}=\frac{1}{2}\left(\left(m_{0}+m_{1}+4 m_{2}\right) \frac{R^{2}}{U^{2}}+J_{1}+4 \frac{J_{2}}{U^{2}}\right) \omega_{1}^{2}=\frac{1}{2} J_{\Sigma} \dot{\varphi}^{2},
$$

де $R$-радіус колеса електромобіля;

$\omega=\frac{d \varphi}{d t}=\dot{\varphi}-$ кутова швидкість вала ТЕП;

$J_{\Sigma}=\left(m_{0}+m_{1}+4 m_{2}\right) \frac{R^{2}}{U^{2}}+J_{1}+4 \frac{J_{2}}{U^{2}}-$ сумарний момент інерції приведений до вала тягового електродвигуна електромобіля.

Під час руху електромобіля на нього діють сили опору [10], до яких належить сила опору повітря $F_{w}$, сила опору дороги, яка складається з сили опору кочення $F_{f}$ та підйому електромобіля $F_{\psi}$. Схема діючих сил у загальному випадку наведена на рисунку 4.

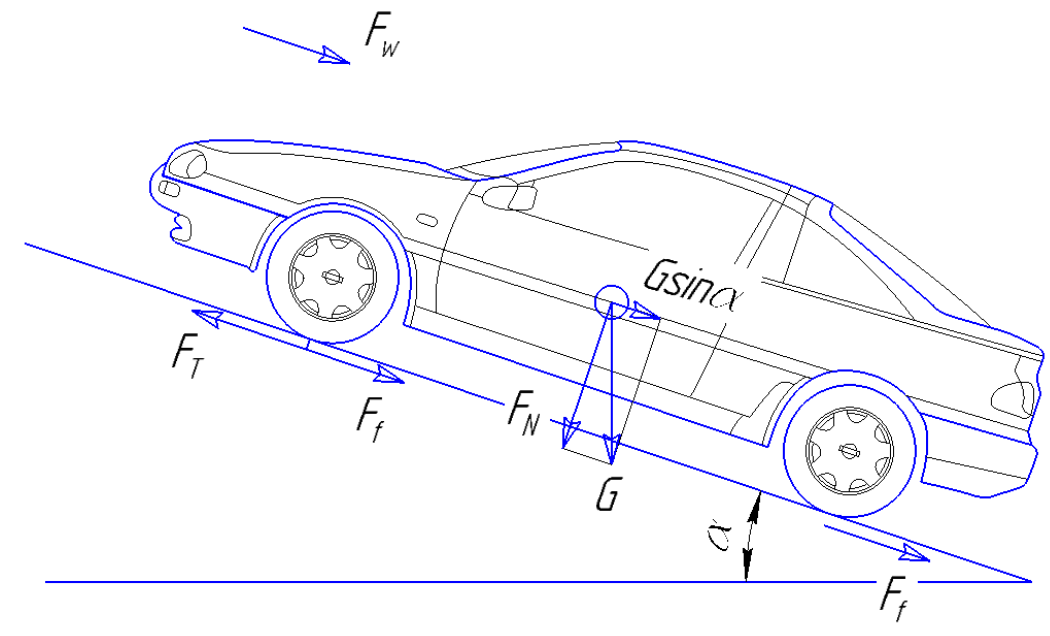

Рис. 4. Схема сил, щчо діють на електромобіль у загальному випадку

Для визначення узагальненої сили $Q$ необхідно обчислити елементарну роботу всіх моментів, що діють на електромобіль під час його руху, на елементарному переміщенні $\partial \varphi$ :

$$
\partial A=\left(M_{1}-M_{f}-M_{w} \mp M_{\psi}-M_{\eta}\right) \partial \varphi,
$$

де $M_{1}$ - крутний момент, що створює ТЕП, $M_{1}=f(\omega)$;

$M_{f}$ - момент сил опору коченню електромобіля, приведений до вала ТЕП;

$M_{w}$ - момент сил опору повітря електромобіля, приведений до вала ТЕП;

$M_{\psi}$ - момент сил опору підйому/спуску електромобіля, приведений до вала ТЕП;

$M_{\eta}$ - момент сил, що враховує втрати в механізмах трансмісії електромобіля, приведений до вала ТЕП.

Виходячи з рівняння (7), одержимо:

$$
Q=\frac{\partial A}{\partial \varphi}=M_{1}-M_{f}-M_{w} \mp M_{\psi}-M_{\eta},
$$

підставимо рівняння (6) та (8) до (3), продиференціюємо його, одержимо рівняння руху електромобіля:

$$
M_{1}-M_{f}-M_{w} \mp M_{\psi}-M_{\eta}=J_{\Sigma} \ddot{\varphi}=J_{\Sigma} \frac{d \omega}{d t} .
$$

Визначимо моменти, що діють на електромобіль під час його руху [8]. Момент сили опору кочення коліс, приведений до вала ТЕП:

$$
M_{f}=\frac{1}{U} F_{N} f=\frac{1}{U} G f \cos \alpha=\frac{1}{U} f g\left(m_{0}+m_{1}+4 m_{2}\right),
$$

де $F_{N}$ - нормальна складова сили тяжіння електромобіля;

$\alpha-$ кут нахилу дороги;

$g$ - прискорення вільного падіння;

$f$ - коефіцієнт опору кочення дороги. 
Момент сил опору повітря електромобіля, приведений до вала ТЕП, можна визначити за формулою:

$$
M_{w}=\frac{1}{2} \rho C_{d} A_{e} v^{2} \frac{R}{U}=\frac{1}{2} \rho C_{d} A_{e}\left(\frac{R}{U}\right)^{3} \omega^{2},
$$

де $\rho$ - густина повітря за нормальних умов;

$C_{d}$ - коефіцієнт аеродинамічного опору кузова електромобіля;

$A_{e}$ - лобова площа електромобіля.

Момент сил опору підйому/спуску електромобіля, приведений до вала ТЕП:

$$
M_{\psi}=G \frac{R}{U} \sin \alpha .
$$

Момент сил, що враховує втрати в механізмах трансмісії електромобіля, приведений до вала ТЕП:

$$
M_{\eta}=\left(1-\eta_{\Sigma}\right) M,
$$

де $\eta_{\Sigma}$ - сумарний ККД механічної передачі, електричних машин та перетворювачів енергії.

Підставимо рівняння (10...13) до виразу (9), одержимо рівняння руху електромобіля:

$$
M \eta_{\Sigma}-F_{N} \frac{f}{U}-\frac{1}{2} \rho C_{d} A_{e}\left(\frac{R}{U}\right)^{3} \omega^{2} \mp G \frac{R}{U} \sin \alpha=J_{\Sigma} \frac{d \omega}{d t} .
$$

Висновки та перспективи подальших досліджень. Отримано рівняння руху електромобіля, що відповідає компонувальній схемі передньопривідного електромобіля. Це дозволяє визначати на етапі проектування електромобілів та при переобладнанні транспортних засобів категорій M1 та N1 в електромобілі їх майбутні експлуатаційні показники з високою точністю. В подальших роботах планується отримати аналітичні вирази для розрахунку характерних точок статичної механічної характеристики тягового електродвигуна. Розробити методику визначення номінальних значень потужності та кутової швидкості тягового електродвигуна. Здійснити розрахунок необхідної статичної механічної характеристики тягового електродвигуна для легкового автомобіля категорії M1 та N1 за умови гарантованого виконання ним стандартизованого їздового циклу.

\section{Список використаної літератури:}

1. Iqbal Husain Electric and hybrid vehicles. Design Fundamentals / Iqbal Husain. - Boca Raton London New York Washington, D.C. : CRC press. -279 p.

2. Тімков О.М. Історія розвитку гібридних силових установок / О.М. Тімков, А.П. Луцик // Вісник Національного транспортного університету. - НТУ, 2012. - № 26 (1). - С. 205-210 [Електронний ресурс]. -Режим доступу : http://nbuv.gov.ua/UJRN/.

3. Грищук O.К. Щодо переобладнання КТЗ шляхом заміни ДВЗ на електромотор / О.К. Грищук, В.С. Гладченко // Тези доповідей. LXXV наукова конференція професорсько-викладацького складу, аспірантів, студентів та співробітників відокремлених структурних підрозділів університету. - К. : НТУ, 2019.

4. Правила ЕЭК ООН № 101-02:2005. Единообразные предписания, касающиеся официального утверждения легковых автомобилей, приводимых в движение только двигателем внутреннего сгорания либо приводимых в движение при помощи гибридного электропривода, в отношении измерения объема выбросов двуокиси углерода и расхода топлива и/или измерения расхода электроэнергии и запаса хода на электротяге, а также транспортных средств категорий М1 и N1, приводимых в движение только при помощи электропривода, в отношении измерения расхода электроэнергии и запаса хода на электротяге.

5. Будніченко В.Б. Аналіз показника енерговитрат транспортних засобів 3 електричним двигуном / В.Б. Будніченко, М.М. Гордіснко // Комунальне господарство міст. Серія : Технічні науки та архітектура. 2019. - Вип. 3. - С. 158-163 [Електронний ресурс]. - Режим доступу : http://nbuv.gov.ua/UJRN/. - DOI 10.33042/2522-1809-2019-3-149-158-163.

6. Вагоны трамвайные пассажирские. Технические условия : ГОСТ 8802-78. - Дата введения - 01.01.79.

7. Колб Ант.А. Теорія електроприводу : навч. посібник / Ант.А. Колб, А.А. Колб. - Д. : Національний гірничий університет, 2006. - 511 с.

8. Теорія електроприводу : підручник / М.Г. Попович, М.Г. Борисюк, В.А. Гаврилюк та ін. // За ред. М.Г. Поповича. - К. : Вища шк., 1993. - 494 с.

9. Гурский Н.Н. Виртуальное проектирование ходовой части мобильных машин / Н.Н. Гурский, Ан.М. Захарик, Ал.М. Захарик // Минск : БНТУ, 2010. -174 с.

10. Автомобілі: Тягово-швидкісні властивості та паливна економічність : навч. посібник / В.П. Сахно, Г.Б. Безбородова, М.М. Маяк, С.М. Шарай. - К. : КВІЦ, 2004. - 174 с.

\section{References:}

1. Iqbal Husain, Electric and hybrid vehicles. Design Fundamentals, CRC press, Boca Raton London New York Washington, D.C., 279 p. 
2. Timkov, O.M. and Lutsyk, A.P. (2012), «History of development of hybrid power plants», Bulletin of the National Transport University, NTU, Vol. 26 (1), pp. 205-210, [Online], available at: http://nbuv.gov.ua/UJRN/

3. Hryshchuk, O.K. and Hladchenko, V.S. (2019), «Regarding the conversion of the KTZ by replacing the internal combustion engine with an electric motor», Abstracts. LXXV Scientific Conference of Teaching Staff, Graduate Students, Students and Employees of Unified Structural Units of the University, NTU, Kyiv.

4. «Uniform Regulations Concerning the Approval of Passenger Cars Driven by an Internal Combustion Engine or Driven by a Hybrid Electric Drive for Measuring Carbon Dioxide Emissions and Fuel Consumption and/or Electricity Measurement and electric range, as well as vehicles of categories M1 and N1, driven only by an electric drive, in relation to the measurement of power consumption and ho and the electric» (2005), UNECE Regulation No. 101-02: 2005.

5. Budnichenko, V.B. and Hordiyenko, M.M. (2019), «Analysis of the energy consumption of vehicles with electric motor», Utilities of cities. Series: Engineering and Architecture, Vol. 3, pp. 158-163, [Online], available at: http://nbuv.gov.ua/ UJRN/, DOI 10.33042 / 2522-1809-2019-3-149-158-163.

6. VNIINMASh, HOST 8802-78 Passenger tram cars. Specifications, Date of introduction 01/01/79.

7. Kolb, Ant.A and Kolb, A.A (2006), Electric Drive Theory, educ. manual, National Mining University, D., 511 p.

8. Popovych, M.H., Borysyuk, M.H. and Havrylyuk, V.A (1993), Electric Drive Theory, A Textbook, Higher School, K., $494 \mathrm{p}$.

9. Hurskyy, N.N, Zakharyk, An.M. and Zakharyk, Al.M. (2010), Virtual design of the undercarriage of mobile machines, BNTU, Minsk, $174 \mathrm{p}$.

10. Sahno, V.P., Bezborodova, H.B., Mayak, M.M. and Sharay, S.M. (2004), Cars: Traction-speed properties and fuel economy, educ. manual, KVITs, K., 174 p.

Тімков Олексій Миколайович - кандидат технічних наук, доцент, доцент кафедри автомобілів Національного транспортного університету.

ORCID: https://orcid.org/0000-0002-7925-7030.

Наукові інтереси:

- $\quad$ конструкція електромобілів та гібридних автомобілів;

- легкові та вантажні автомобілі, автопоїзди.

E-mail: alextimkov@gmail.com.

Гладченко Володимир Сергійович - аспірант кафедри туризму Національного транспортного університету.

ORCID: https://orcid.org/0000-0001-5783-4880.

Наукові інтереси:

- переобладнання в електромобілі та гібридні автомобілі.

E-mail: autokaf.ntu@gmail.com.

Гордіснко Микола Максимович - аспірант, асистент кафедри технічної експлуатації автомобілів та автосервісу Національного транспортного університету.

ORCID: http://orcid.org/0000-0002-8993-789X.

Наукові інтереси:

- експлуатація та технічне обслуговування електромобілів та гібридних автомобілів;

- дослідження економічних показників транспортних засобів з електричним двигуном.

E-mail: gordienkonikolaj@ukr.net. 